\title{
24. MELTING RELATIONS AND VISCOSITY OF AN ABYSSAL OLIVINE THOLEIITE
}

\author{
T. Fujii, ${ }^{1}$ Geophysical Laboratory, Carnegie Institution of Washington, Washington, D.C. \\ and \\ I. Kushiro and K. Hamuro, Geological Institute, University of Tokyo, Tokyo
}

\begin{abstract}
Melting experiments at 1 atmosphere on an olivine tholeiite, Sample 395A-8-1, $50 \mathrm{~cm}$, suggest that the magma erupted at or near $1215^{\circ} \mathrm{C}$. On the basis of the experiments at high pressures up to 12 kbar, it appears that olivine tholeiite magma could be equilibrated with plagioclase lherzolite at a depth of about $25 \mathrm{~km}$ or be formed by fractional crystallization from more magnesian magma at depths shallower than $25 \mathrm{~km}$. It also appears that the process of fractional crystallization is most likely at a depth of $25 \mathrm{~km}$ if pyroxenes take an important part in such a process.

Viscosity and density measurements of melt of the sample at high pressure suggest that owing to low viscosity, olivine and pyroxene sink rapidly in the melt, whereas plagioclase floats. The phenocrysts of porphyritic basalt, therefore, do not always represent the first liquidus phase. Some plagioclase-phyric tholeiite may be derived from olivine tholeiite magma by floating of plagioclase phenocrysts at high pressures.
\end{abstract}

\section{INTRODUCTION}

Petrography and geochemistry of oceanic basalts have been studies by many investigators (e.g., Bryan et al., 1976). Experimental data on such rocks are relatively scarce, however. It is important to know the melting relations of oceanic basalt at 1 atmosphere and at high pressures, in order to understand the genesis of oceanic basalt magmas. Viscosity and density data on oceanic basalt magma at high pressures are also necessary to understand processes of fractionation at high pressures. For these reasons, melting experiments and density and viscosity measurements have been conducted on melt of a sample collected near the Mid-Atlantic Ridge during Leg 45.

Sample 395A-8-1, $50 \mathrm{~cm}$, was recovered at a depth of about 140 meters beneath the ocean floor, and belongs to type $\mathrm{A}_{2}$ aphyric tholeiite. This sample is glassy olivine tholeiite, probably from the chilled margin of a pillow basalt, containing very small amounts of olivine microphenocryst $\left(0.3 \mathrm{~mm}\right.$ across, $\left.\mathrm{Fo}_{85}\right)$ and platy skeletal crystals of olivine $\left(0.1 \mathrm{~mm}\right.$ long, $\left.\mathrm{Fo}_{83}\right)$ set in the glassy matrix. The modal amount of olivine microphenocrysts is less than 1 per cent. The microphenocryst also shows skeletal habit, indicating that the microphenocrysts grew rapidly probably just before or at the time of eruption of magma. It may thus be concluded that this sample represents the liquid composition.

The chemical composition and CIPW norm of the sample are listed in Table 1. This sample is one of the

${ }^{1}$ Now at Geological Institute, University of Tokyo, Tokyo, Japan. most magnesian rocks $\left(\mathrm{Mg} / \mathrm{Mg}+\mathrm{Fe}^{*}=0.57\right)$ among the aphyric olivine tholeiite recovered on Leg 45 , and also has high $\mathrm{Ni}$ content ( $178 \mathrm{ppm}$ ), low $\mathrm{K}_{2} \mathrm{O}$ content $(0.13 \mathrm{wt} \%)$, and low ignition loss (Bougault et al., this volume). It therefore appears to be the least fractionated and least altered olivine tholeiite recovered during Leg 45.

\section{MELTING EXPERIMENTS}

The 1-atmosphere melting experiments were performed at $\mathrm{pO}_{2}=10^{-8} \mathrm{bar}$, where $\mathrm{pO}_{2}$ was controlled by changing the mixing ratio of $\mathrm{CO}_{2}$ and $\mathrm{H}_{2}$ gases. Powdered samples were pressed into pellets and a fragment of the pellet tied with fine Pt wire was fused at $1300^{\circ} \mathrm{C}$ and $\mathrm{pO}_{2}=10^{-8}$ bar for 15 minutes to make a glass sphere. These glass spheres, held on fine $\mathrm{Pt}$ wire, were used through runs in order to minimize iron loss. Runs were quenched by dropping the material into a metal cup cooled with ice from outside.

The high-pressure melting experiments were carried out in graphite capsules in a solid-media apparatus (Boyd and England, 1960) using the piston-out method. The powdered samples were dried at $110^{\circ} \mathrm{C}$ for several days and heated in air in graphite capsules at about $1000^{\circ} \mathrm{C}$ for a minute just before the experiment to eliminate water. The oxygen fugacity of each run was within the stability field of wüstite (Thompson and Kushiro, 1972).

The results of melting experiments are listed in Tables $2 \mathrm{~A}$ and $2 \mathrm{~B}$, and plotted in Figure 1. Olivine is the liquidus phase at pressures below 8 kbar. Above this pressure, $\mathrm{Ca}$-rich clinopyroxene appears on the liqui- 
TABLE 1

Chemical Composition and

CIPW Norm of Starting

Material, Sample

$395 \mathrm{~A}-8-1,50 \mathrm{~cm}$

\begin{tabular}{lccr}
\hline \multicolumn{2}{c}{ Composition } & \multicolumn{2}{c}{ CIPW norm } \\
\hline $\mathrm{SiO}_{2}$ & 50.0 & $\mathrm{Or}$ & 0.78 \\
$\mathrm{TiO}_{2}$ & 1.64 & $\mathrm{Ab}$ & 22.75 \\
$\mathrm{Al}_{2} \mathrm{O}_{3}$ & 15.0 & $\mathrm{An}$ & 28.23 \\
$\mathrm{FeO}^{\mathrm{a}}$ & 11.2 & $\mathrm{Di}$ & 19.83 \\
$\mathrm{MnO}$ & 0.22 & $\mathrm{Hy}$ & 14.53 \\
$\mathrm{MgO}^{2}$ & 8.40 & $\mathrm{Ol}$ & 10.79 \\
$\mathrm{CaO}$ & 10.6 & $\mathrm{Il}$ & 3.09 \\
$\mathrm{Na}_{2} \mathrm{O}$ & 2.70 & & \\
$\mathrm{~K}_{2} \mathrm{O}$ & 0.13 & & \\
$\mathrm{Total}$ & 99.9 & & \\
\hline
\end{tabular}

${ }^{\mathrm{a}}$ Total iron as $\mathrm{FeO}$.

TABLE 2A

Results of One-Atmosphere Experiments on an Olivine Tholeiite, Sample 395A-9-1, $50 \mathrm{~cm}\left(\mathrm{pO}_{2}=10^{-8} \mathrm{bar}\right)$

\begin{tabular}{crl}
\hline $\begin{array}{c}\text { Temperature } \\
\left({ }^{\circ} \mathrm{C}\right)\end{array}$ & $\begin{array}{c}\text { Time } \\
(\mathrm{hr})\end{array}$ & \multicolumn{1}{c}{ Products } \\
\hline 1220 & 19 & $\mathrm{Gl}$ \\
1210 & 20 & $\mathrm{Ol}+\mathrm{Gl}$ \\
1200 & 20 & $\mathrm{Ol}+\mathrm{Gl}$ \\
1190 & 27 & $\mathrm{Ol}+\mathrm{Sp}+\mathrm{Gl}$ \\
1180 & 42 & $\mathrm{Ol}+\mathrm{Pl}+\mathrm{Sp}+\mathrm{Gl}$ \\
1170 & 43 & $\mathrm{Ol}+\mathrm{Pl}+\mathrm{Sp}+\mathrm{Gl}$ \\
1160 & 42 & $\mathrm{O} 1+\mathrm{Pl}+\mathrm{Sp}+\mathrm{Gl}$ \\
1150 & 45 & $\mathrm{Ol}+\mathrm{Pl}+\mathrm{Cpx}+\mathrm{Gl}$ \\
1120 & 64 & $\mathrm{Ol}+\mathrm{Pl}+\mathrm{Cpx}+$ Opaque minerals + Gl \\
1100 & 118 & Fine crystalline aggregates \\
\hline
\end{tabular}

Note: Abbreviations: Ol, olivine; $\mathrm{Cpx}$, clinopyroxene, $\mathrm{Pl}$, plagioclase; Sp, spinel; Gl, glass.

dus. Although spinel is the second mineral to crystallize at $1 \mathrm{~atm}$, it was not detected in the high-pressure experiments. At about $8 \mathrm{kbar}$, olivine, plagioclase, $\mathrm{Ca}$ rich clinopyroxene, and orthopyroxene crystallized within $10^{\circ} \mathrm{C}$ below the liquidus, indicating that the liquid lies close to the four-phase boundary. This may also mean that orthopyroxene is on the liquidus at or near this pressure.

\section{DENSITY AND VISCOSITY MEASUREMENTS AT HIGH PRESSURES}

The densities of melt were measured by a fallingsphere method, using spheres with different densities. To reduce the thermal gradients within the graphite capsule, specially designed furnaces (Kushiro, 1976)
TABLE 2B

Results of High-Pressure Melting Experiments on an Olivine Tholeiite, Sample 395A-8-1, $50 \mathrm{~cm}$

\begin{tabular}{cccl}
\hline $\begin{array}{c}\text { Pressure } \\
\text { (kbar) }\end{array}$ & $\begin{array}{c}\text { Temperature } \\
\left({ }^{\circ} \mathrm{C}\right)\end{array}$ & $\begin{array}{c}\text { Time } \\
(\mathrm{min})\end{array}$ & \multicolumn{1}{c}{ Products } \\
\hline 5 & 1215 & 50 & $\mathrm{Ol}+\mathrm{Gl}$ \\
7.5 & 1230 & 90 & $\mathrm{Gl}$ \\
7.5 & 1220 & 90 & $\mathrm{Ol}+\mathrm{Pl}+\mathrm{Gl}$ \\
7.5 & 1210 & 95 & $\mathrm{Ol}+\mathrm{Pl}+\mathrm{Cpx}+\mathrm{Opx}(?)+\mathrm{Gl}$ \\
7.5 & 1175 & 90 & $\mathrm{Ol}+\mathrm{Pl}+\mathrm{Cpx}+\mathrm{Gl}$ \\
8.2 & 1225 & 40 & $\mathrm{Ol}+\mathrm{Cpx}+\mathrm{Gl}$ \\
8.2 & 1215 & 80 & $\mathrm{Ol}+\mathrm{Cpx}+\mathrm{Opx}+\mathrm{Pl}+\mathrm{Gl}$ \\
8.2 & 1205 & 95 & $\mathrm{Ol}+\mathrm{Cpx}+\mathrm{Opx}+\mathrm{Pl}+\mathrm{Gl}$ \\
9 & 1215 & 90 & $\mathrm{Cpx}+\mathrm{Opx}+\mathrm{Pl}+\mathrm{Gl}$ \\
10 & 1270 & 80 & $\mathrm{Gl}$ \\
10 & 1250 & 90 & $\mathrm{Cpx}+\mathrm{Gl}$ \\
10 & 1230 & 70 & $\mathrm{Cpx}+\mathrm{Pl}+\mathrm{Gl}$ \\
12 & 1300 & 20 & $\mathrm{Gl}$ \\
12 & 1260 & 90 & $\mathrm{Cpx}+\mathrm{Gl}$ \\
\hline
\end{tabular}

Note: Abbreviations: Ol, olivine; $\mathrm{Cpx}$, clinopyroxene; Opx, orthopyroxene, $\mathrm{Pl}$, plagioclase; Gl, glass.

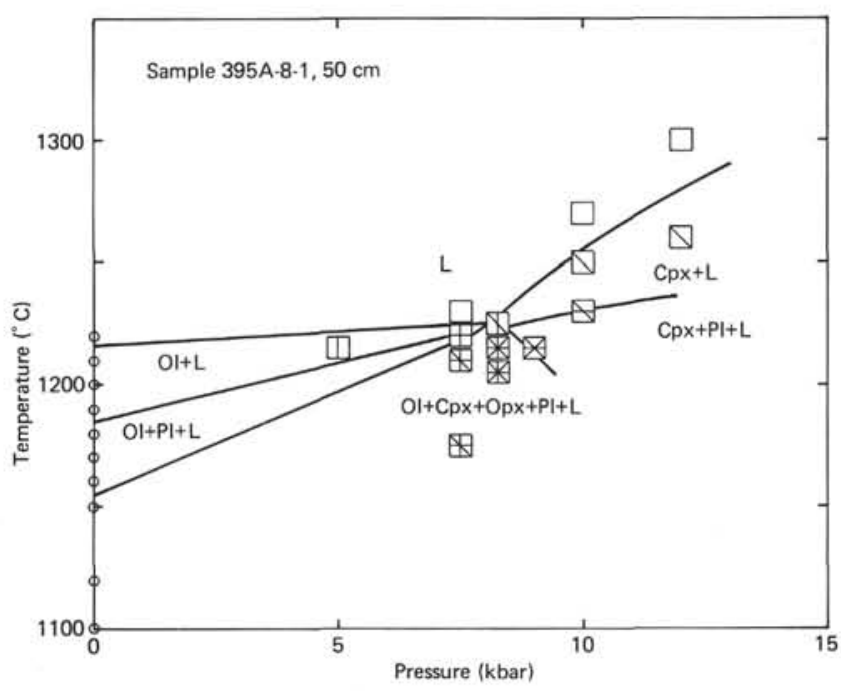

Figure 1. Phase relations of an olivine tholeiite, Sample $395 \mathrm{~A}-8-1,50 \mathrm{~cm}$

were used. Spheres of olivine ( $8 \mathrm{kbar}$ measurement) or chromian diposide ( $12 \mathrm{kbar}$ measurement) were placed at the top, and spheres of boron nitride and plagioclase $\left(\mathrm{An}_{65}\right)$ were placed at the bottom of the charge when it was loaded. The distances the spheres dropped (olivine or chromian diopside) or floated (boron nitride and plagioclase) were measured with a microscale after quenching of each run (Table 3 ). There was no evidence of reaction between melt and spheres.

The moving velocity, $V$, of a sphere with radius of $r$ in the melt with viscosity $\eta$ is

$$
V=\frac{2 r^{2} \cdot \Delta \rho \cdot g}{9 \eta}=\frac{\ell}{\Delta t}
$$


TABLE 3

Results of Runs for Density Measurement

\begin{tabular}{cccccc}
\hline $\begin{array}{c}\text { Pressure } \\
(\mathrm{kbar})\end{array}$ & $\begin{array}{c}\text { Temperature } \\
\left({ }^{\circ} \mathrm{C}\right)\end{array}$ & $\begin{array}{c}\text { Time } \\
(\mathrm{min})\end{array}$ & $\begin{array}{c}\text { Diameter } \\
(\mathrm{mm})\end{array}$ & $\begin{array}{c}\text { Sinking } \\
\text { distance } \\
(\mathrm{mm})\end{array}$ & Sphere \\
\hline 8 & 1250 & 10 & 0.70 & 2.6 & $\mathrm{Ol}$ \\
8 & 1250 & 10 & 0.80 & 3.3 & $\mathrm{Ol}$ \\
8 & 1250 & 10 & 1.0 & -1.4 & $\mathrm{Pl}$ \\
8 & 1250 & 10 & 0.60 & -2.3 & $\mathrm{BN}$ \\
12 & 1300 & 10 & 0.50 & 2.9 & $\mathrm{Cpx}$ \\
12 & 1300 & 10 & 0.80 & -2.3 & $\mathrm{Pl}$ \\
12 & 1300 & 10 & 0.60 & -5.0 & $\mathrm{BN}$ \\
\hline
\end{tabular}

Note: Abbreviations: Ol, olivine (Fo91); Pl, plagioclase (An65); $\mathrm{BN}$, fired born nitride, $\mathrm{Cpx}$, chromian diopside.

where $l$ is the distance the sphere moved during time interval $\Delta t, \rho$ is the density difference between spheres and melt, and $g$ is the gravity constant. For the spheres with different densities in the same melt, the following relation is derived from Equation 1:

$$
\frac{\ell_{1}}{r_{1}{ }^{2}\left(\rho_{1}-\rho_{0}\right)}=\frac{\ell_{2}}{r_{2}{ }^{2}\left(\rho_{2}-\rho_{0}\right)}=\frac{2 \cdot \mathrm{g} \cdot \Delta t}{9 \eta}
$$

where $l_{1}$ and $l_{2}$ are the moved distances, $r_{1}$ and $r_{2}$ are the radii, $\rho_{1}$ and $\rho_{2}$ are the densities of spheres 1 and 2 , respectively, and $\rho_{0}$ is the density of melt. As three spheres with different densities were used in each run, the density of the melt was calculated by the leastsquares method, on the basis of equation 2. Although the densities of spheres were 3.33 (olivine and chromian diopside), 2.70 (plagioclase, $\mathrm{An}_{65}$ ) and 2.29 (boron nitride) at 1 atmosphere and at room temperature, $3.23,2.68$, and 2.25 were used in the calculation to take into account the effects of compressibility and thermal expansion (Birch, 1966; Skinner, 1966; Yagi, unpublished data).

The calculated densities were $2.80 \mathrm{~g} / \mathrm{cm}^{3}( \pm 0.03)$ both at $1250^{\circ} \mathrm{C}$ and $8 \mathrm{kbars}$ and at $1300^{\circ} \mathrm{C}$ and 12 kbar. This value is larger than that calculated from the chemical composition, according to Bottinga and Weill (1970). The difference is about $0.1 \mathrm{~g} / \mathrm{cm}^{3}$ when iron is treated as ferrous, and about $0.2 \mathrm{~g} / \mathrm{cm}^{3}$ when iron is treated as ferric.

The viscosity measurements were based on the method described by Kushiro et al. (1976), except that olivine spheres were used at $8 \mathrm{kbar}$ instead of chromian diopside spheres. Run time ranged from 3 minutes to 10 minutes.

The sinking velocities were calculated from results of at least two runs with different run times at the same conditions (Table 4 ). They were $0.36 \mathrm{~mm}$ per minute for spheres of olivine with radius of $0.40 \mathrm{~mm}$ and 0.28 $\mathrm{mm}$ per minute for spheres of olivine with radius of $0.35 \mathrm{~mm}$ at $8 \mathrm{kbar}$ and $1250^{\circ} \mathrm{C} ; 0.48 \mathrm{~mm}$ per minute for spheres of chromian diopside with radius of 0.30 $\mathrm{mm}$ at $12 \mathrm{kbar}$ and $1300^{\circ} \mathrm{C}$; and $0.2 \mathrm{~mm}$ per minute
TABLE 4

Results of Runs for Viscosity Measurement

\begin{tabular}{cccccc}
\hline $\begin{array}{c}\text { Pressure } \\
\text { (kbar) }\end{array}$ & $\begin{array}{c}\text { Temperature } \\
\left({ }^{\circ} \mathrm{C}\right)\end{array}$ & $\begin{array}{c}\text { Time } \\
(\mathrm{min})\end{array}$ & $\begin{array}{c}\text { Diameter } \\
(\mathrm{mm})\end{array}$ & $\begin{array}{c}\text { Sinking } \\
\text { distance } \\
(\mathrm{mm})\end{array}$ & Sphere \\
\hline 8 & 1250 & 6 & 0.80 & 1.9 & $\mathrm{Ol}$ \\
8 & 1250 & 6 & 0.71 & 1.5 & $\mathrm{Ol}$ \\
$8^{\mathrm{a}}$ & 1250 & 10 & 0.80 & 3.3 & $\mathrm{Ol}$ \\
$8^{\mathrm{a}}$ & 1250 & 10 & 0.70 & 2.6 & $\mathrm{Ol}$ \\
12 & 1275 & 3 & 0.70 & 0.5 & $\mathrm{Cpx}$ \\
12 & 1275 & 6 & 0.72 & 1.0 & $\mathrm{Cpx}$ \\
12 & 1275 & 10 & 0.70 & 1.8 & $\mathrm{Cpx}$ \\
12 & 1300 & 5 & 0.60 & 1.7 & $\mathrm{Cpx}$ \\
12 & 1300 & 9 & 0.60 & 3.6 & $\mathrm{Cpx}$ \\
\hline
\end{tabular}

Note: Abbreviations: Ol, olivine $\left(\mathrm{Fo}_{91}\right)$; $\mathrm{Cpx}$, chromian diopside ${ }^{\text {a}}$ From Table 3.

for spheres of chromian diopside with radius of about $0.35 \mathrm{~mm}$ at $12 \mathrm{kbar}$ and $1275^{\circ} \mathrm{C}$ (Figure 2). The viscosities of melt were calculated by Stokes' law, using the density data described above, and corrections for wall effects were based on the Faxen correction (Shaw, 1963). The results are shown in Figure 3 with the 1-atmosphere viscosities calculated according to model of Bottinga and Weill (1972). The relatively high viscosity at $12 \mathrm{kbar}$ and $1275^{\circ} \mathrm{C}$ probably results from the presence of clinopyroxene crystals because it is below the liquidus temperature. The calculated 1-atmosphere viscosity is clearly higher than the viscosity at high pressures at the same temperature.

\section{DISCUSSION}

The 1-atmosphere experiments suggest that olivine begins to crystallize at $1215^{\circ} \mathrm{C}$ in this magma. The ex-

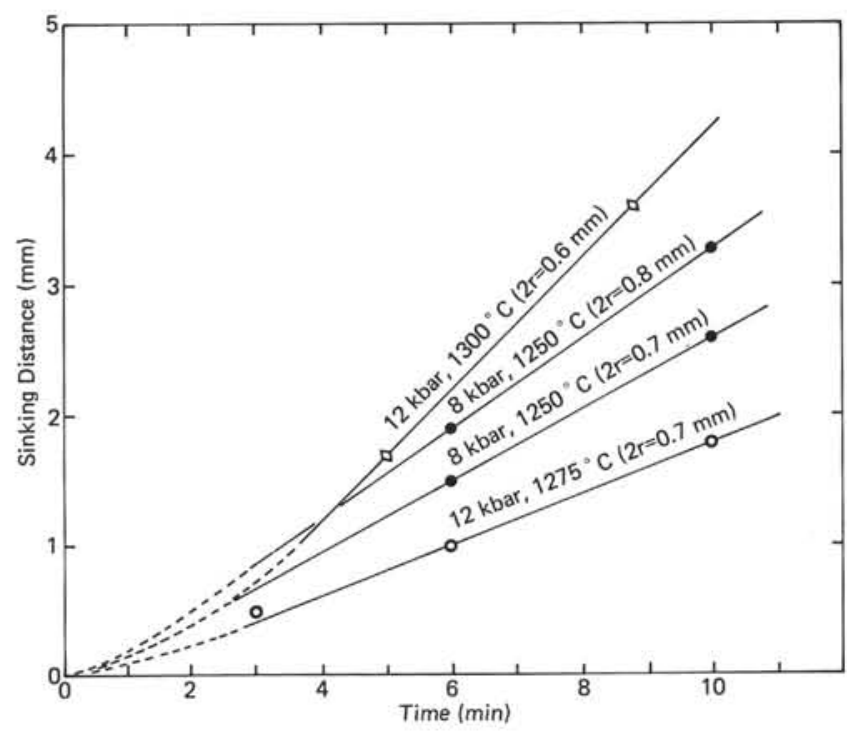

Figure 2. Time and distance relations for sinking of spheres in melts of an olivine tholeiite, Sample 395A-8-1, $50 \mathrm{~cm}$. Solid circle, olivine sphere; open circle and square, chromian diopside sphere. 


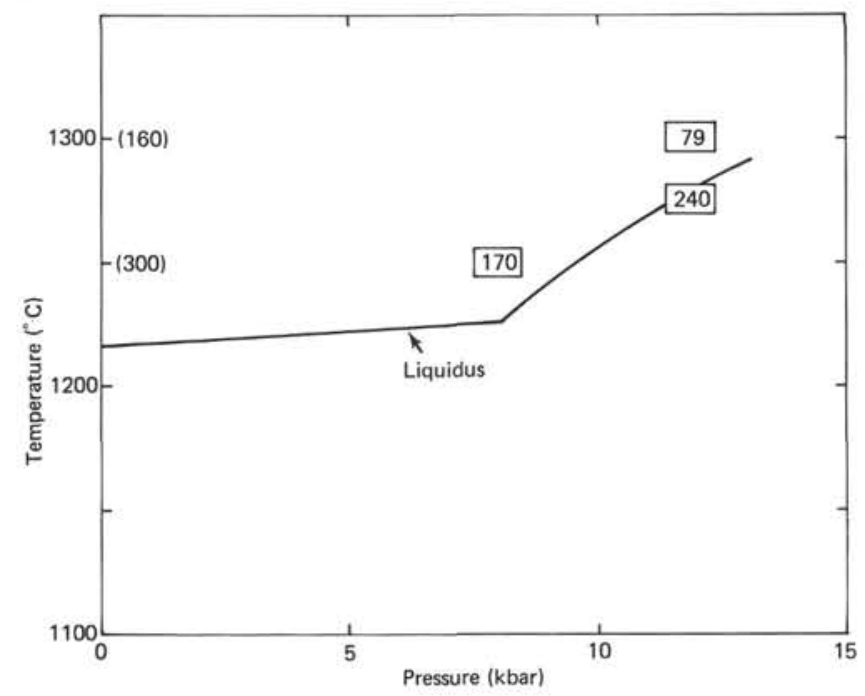

Figure 3. Viscosity of an olivine tholeiite melt. Numbers in rectangles indicate measured viscosity (poise). Those in parentheses are calculated according to the method of Bottinga and Weill (1972).

istence of a small amount of olivine microphenocrysts in the sample indicates that this magma erupted at or near $1215^{\circ} \mathrm{C}$.

O'Hara (1968) stated that abyssal tholeiite cannot be a primary magma derived by partial melting of mantle peridotite, because most abyssal tholeiites do not coexist with orthopyroxene at any pressure. As shown above, however, the composition of this olivine tholeiite is close to the olivine-plagioclase-Ca-rich clinopyroxene-orthopyroxene-liquid boundary at about 8 kbar. And it may be potentially a primary magma in the sense of O'Hara (1968). O'Hara (1973) also stated that abyssal tholeiite cannot be a partial melting product of mantle peridotite, because the near-liquidus orthopyroxene is not so magnesian as those in mantle peridotities. Unfortunately, it was impossible to obtain the exact analysis of orthopyroxene without contamination of glass, because of its small grain size. The olivine coexisting with orthopyroxene was $\mathrm{Fo}_{86}$. Because the Fe-Mg partitioning between olivine and orthopyroxene is almost unity and the partition coefficient is insensitive to temperature and pressure, the composition of orthopyroxene should be close to $\mathrm{En}_{86}$. Some of the mantle-derived peridotites contain similar olivine and orthopyroxene (Kuno and Aoki, 1970). It is possible that under anhydrous conditions this olivine tholeiite magma can coexist in equilibrium with plagioclase lherzolite of oceanic upper mantle at a depth of about 25 kilometers.

Melting relations similar to the results given above were obtained on an olivine tholeiite dredged from the Mid-Atlantic Ridge at $45^{\circ} \mathrm{N}$ (Kushiro, 1973). In that case, the pressure and temperature conditions for the five-phase assemblage $(\mathrm{Ol}+\mathrm{Cpx}+\mathrm{Opx}+\mathrm{P} 1+$ Liq) are nearly the same $\left(7.5 \mathrm{kbar}, 1220^{\circ} \mathrm{C}\right)$, in spite of the different chemical compositions (espeically in $\mathrm{MgO}$ and $\mathrm{FeO}$ ) of the two starting materials. The melting relations of a magnesian olivine tholeiite from the
FAMOUS area (Hodges, 1976; Fujii, unpublished data) are also similar, but the liquidus temperature is much higher because of high $\mathrm{Mg} / \mathrm{Fe}$ ratios. The olivine tholeiite used in this experiment and that by Kushiro (1973) may be products of a lower degree of melting than that of FAMOUS area (Hodges, 1976). It may be concluded, therefore, that some of the abyssal olivine tholeiite may be equilibrated with the upper mantle material at about $8 \mathrm{kbar}$, and that the compositional variations may result from the difference in degree of melting or different degrees of depletion in the source materials.

Although it was emphasized above that the olivine tholeiite used here may represent a primary magma formed by direct partial melting of upper mantle materials, it is also possible that this magma is a product of fractional crystallization of an even more magnesian primary magma; but such a fractionation process is limited to depths shallower than $25 \mathrm{~km}$ where olivine is the first liquidus phase. Considering the decrease of viscosity with increasing of pressure (Figure 3 ), however, such a fractionation process is more effective at high pressures than near 1 atmosphere.

The diverse compositional variations of abyssal olivine tholeiite have been explained by a process of separation of olivine and plagioclase from a primary magma (Kay et al., 1970; Hart, 1971). Recently, however, Shibata and Fox (1975), Presnall and O'Donnell (1976), and Clague and Bunch (1976) argued that the diversity of abyssal olivine tholeiite cannot be explained by the separation of olivine and/or plagioclase alone, but requires the additional separation of $\mathrm{Ca}$-rich clinopyroxene. The above experimental results suggest that such a differentiation process is possible at about 8 kbar where olivine, pyroxenes, and plagioclase are near-liquidus phases.

Recently, three different types of abyssal tholeiite have been distinguished on the basis of the primary phase: olivine tholeiite, plagioclase tholeiite, pyroxene tholeiite (Shido et al., 1971; Hekinian and Aumento, 1973; Shido et al., 1974; Bougault and Hekinian, 1974). In those arguments, it is assumed that the phenocrysts or microphenocrysts represent the first liquidus phase and the bulk compositions represent the compositions of liquid. The low viscosity (Figure 3 ) and the high density $\left(2.80 \mathrm{~g} / \mathrm{cm}^{3}\right)$ of melt at high pressures, however, suggest that olivine and pyroxenes sink rapidly, whereas plagioclase floats in the magma. Consequently, the phenocrysts do not always represent the first liquidus phase, and the bulk compositions of porphyritic rock do not always represent the compositions of liquid. These considerations suggest that it is possible to derive two different types of tholeiites, plagioclase-phyric tholeiite and olivine-phyric tholeiite, from an olivine tholeiite parent magma. Some abyssal plagioclase-phyric basalts contain huge glomerocrystic plagioclase phenocrysts (xenocryst) and smaller euhedral olivine (e.g., Melson and Thompson, 1971; Blanchard et al., 1976). Such rocks may be formed by the floating of plagioclase at some depth and the crystallization of euhedral olivine in a shallower environment. 


\section{ACKNOWLEDGMENTS}

The authors are indebted to Dr. B. O. Mysen for his critical review. They also are grateful to Dr. D. H. Eggler who has critically read a preliminary version of the paper.

\section{REFERENCES}

Birch, F., 1966. Compressibility; elastic constants. In Clark, S. P. (Ed.), Handbook of physical constants: G.S.A. Mem., v. 97, p. 97-174.

Blanchard, D. P., Rhodes, J. M., Dungan, M. A., Rodgers, K.V., Donaldson, C. H., Brannon, J. C., Jacobs, J. W., and Gibson, E. K., 1976. The chemistry and petrology of basalts from Leg 37 of the Deep Sea Drilling Project, J. Geophys. Res., v. 81, p. 4231-4246.

Bryan, W. B., Thompson, G., Frey, F. A., and Dickey., J. S., 1976. Inferred geologic settings and differentiation in basalts from the Deep Sea Drilling Project, J. Geophys. Res., v. 81, p. $4285-4304$.

Bottinga, Y. and Weil, D. F., 1970. Densities of liquid silicate systems calculated from partial molar volumes of oxide components, Am. J. Sci., V. 269, p. 169-182.

1972. The viscosity of magmatic silicate liquids: A model for calculation, Am. J. Sci., v. 272, p. 438475.

Bougault, H. and Hekinian, R., 1974. Rift valley in the Atlantic Ocean near $36^{\circ} 50^{\prime} \mathrm{N}$; petrology and geochemistry of basaltic rocks, Earth. Planet. Sci. Lett., 24, p. 249-261.

Boyd, F. R. and England, J. L., 1960. Apparatus for phase equilibrum measurements at pressures up to $50 \mathrm{~kb}$ and temperatures up to $1750^{\circ} \mathrm{C}$, J. Geophys. Res., v. 65 , no. 2 , p. 741-748.

Clague, D. A. and Bunch, T. E., 1976. Formation of ferro-basalt at east Pacific midocean spreading centers, J. Geophy. Res., v. 81, p. 4247-4256.

Hart, S. R., 1971. K, Rb, Cs, $\mathrm{Sr}$ and $\mathrm{Ba}$ contents and $\mathrm{Sr}$ isotopic ratios of ocean floor basalts, Phil. Trans. Roy. Soc. London, ser. A, v. 268 , p. $573-587$.

Hekinian, R. and Aumento, F., 1973. Rocks from the Gibbs fracture zone and Minia seamount near $53^{\circ} \mathrm{N}$ in the Atlantic ocean, Marine Geol., v. 14, p. 47-72.

Hodges, F. N. and Bender, J. F., 1976. Petrogenesis of basalt glass from project FAMOUS: Experimental study from 1 atm to 15 kbar (Abstract). Geol. Soc. Am. Ann. Mt. p. 920.

Kay, R., Hubrand, N. J., and Gast, P. W., 1970. Chemical characteristics and origin of ocean ridge volcanic rocks, $J$. Geophy. Res., v. 75., p. 1585-1613.

Kuno, H. and Aoki, K., 1970. Chemistry of ultramafic nodules and their bearing on the origin of basaltic magmas, Phys. Earth Planet. Interiors, v. 3, p. 273-301.

Kushiro, I., 1973. Origin of some magmas in oceanic and circum-oceanic regions, Tectonophysics, v. 17, p. 211-222.

1976. Changes in viscosity and structure of melt of $\mathrm{NaAlSi}_{2} \mathrm{O}_{6}$ composition at high pressures, J. Geophys. Res., v. 81, p. 6347-6350.

Kushiro, I., Yoder, H. S., Jr. and Mysen, B. O., 1976. Viscosities of basalt and andesite melts at high pressures, J. Geophy. Res., v. 81, p. 6351-6356.

Melson, W. G. and Thompson, G., 1971. Petrology of a transform fault zone and adjacent ridge segments, Phil. Trans. Roy. Soc. London, ser. A, v. 268, p. 423-441.

O'Hara, M. J., 1968. Are ocean floor basalts primary magma?, Nature, 220, p. 683-686.

O'Hara, M. J., 1973. Non-primary magmas and dubious mantle plume beneath Iceland, Nature, v. 243, p. 507-508.

Presnall, D. C. and O'Donnel, T. H., 1976. Origin of basalts from $25^{\circ}-29^{\circ} \mathrm{N}$ on the Mid-Atlantic Ridge (abstract). EOS, Am. Geophys. Un. Trans., v. 57, p. 341.

Shaw, H. R., 1963. Obsidian $-\mathrm{H}_{2} \mathrm{O}$ viscosities at 1000 and 2000 bars in the temperature range $700^{\circ} \mathrm{C}$ to $900^{\circ} \mathrm{C}$, J. Geophys. Res., v. 68, p. 6337-6343.

Shibata, T. and Fox, P. J., 1975. Fractionation of abyssal tholeiites: samples from the Oceanographer fracture zone $\left(35^{\circ} \mathrm{N}, 35^{\circ} \mathrm{W}\right)$, Earth. Planet. Sci. Lett., v. 27, p. 62-72.

Shido, F., Miyashiro, A., and Ewing, M., 1971. Crystallization of abyssal tholeiites, Contrib. Mineral. Petrol., v. 31, p. 251-266.

1974. Basalts and serpentinite from the Puerto Rico Trench, 1. Petrology, Marine Geol., v. 16, p. 191-203.

Skinner, B. J., 1966. Thermal expansion. In Clark, S. P. (Ed.), Handbook of physical constants: G.S.A. Mem., v. 97, p. $75-96$.

Thompson, R. N. and Kushiro, I., 1972. The oxygen fugacity within graphite capsules in piston-cylinder apparatus at high pressures, Carnegie Inst. Wash. Yearb., v. 71, p. 615-616. 